University at Albany, State University of New York

Scholars Archive

Fall 2019

\title{
Teaching Critical Thinking and Metaliteracy Through OER: Theory and Practice in a Course Collaboration
}

Trudi E. Jacobson

University at Albany, State University of New York, tjacobson@albany.edu

Sally Friedman

University at Albany, State University of New York, sfriedman2@albany.edu

Follow this and additional works at: https://scholarsarchive.library.albany.edu/ulib_fac_scholar

Part of the Higher Education Commons, Information Literacy Commons, and the Political Science Commons

\section{Recommended Citation}

Jacobson, Trudi E. and Friedman, Sally, "Teaching Critical Thinking and Metaliteracy Through OER: Theory and Practice in a Course Collaboration" (2019). University Libraries Faculty Scholarship. 125.

https://scholarsarchive.library.albany.edu/ulib_fac_scholar/125

This Article is brought to you for free and open access by the University Libraries at Scholars Archive. It has been accepted for inclusion in University Libraries Faculty Scholarship by an authorized administrator of Scholars Archive. For more information, please contact scholarsarchive@albany.edu. 


\title{
Teaching Critical Thinking and Metaliteracy Through OER: Theory and Practice in a
} Course Collaboration

Trudi E. Jacobson and Sally Friedman, University at Albany, New York

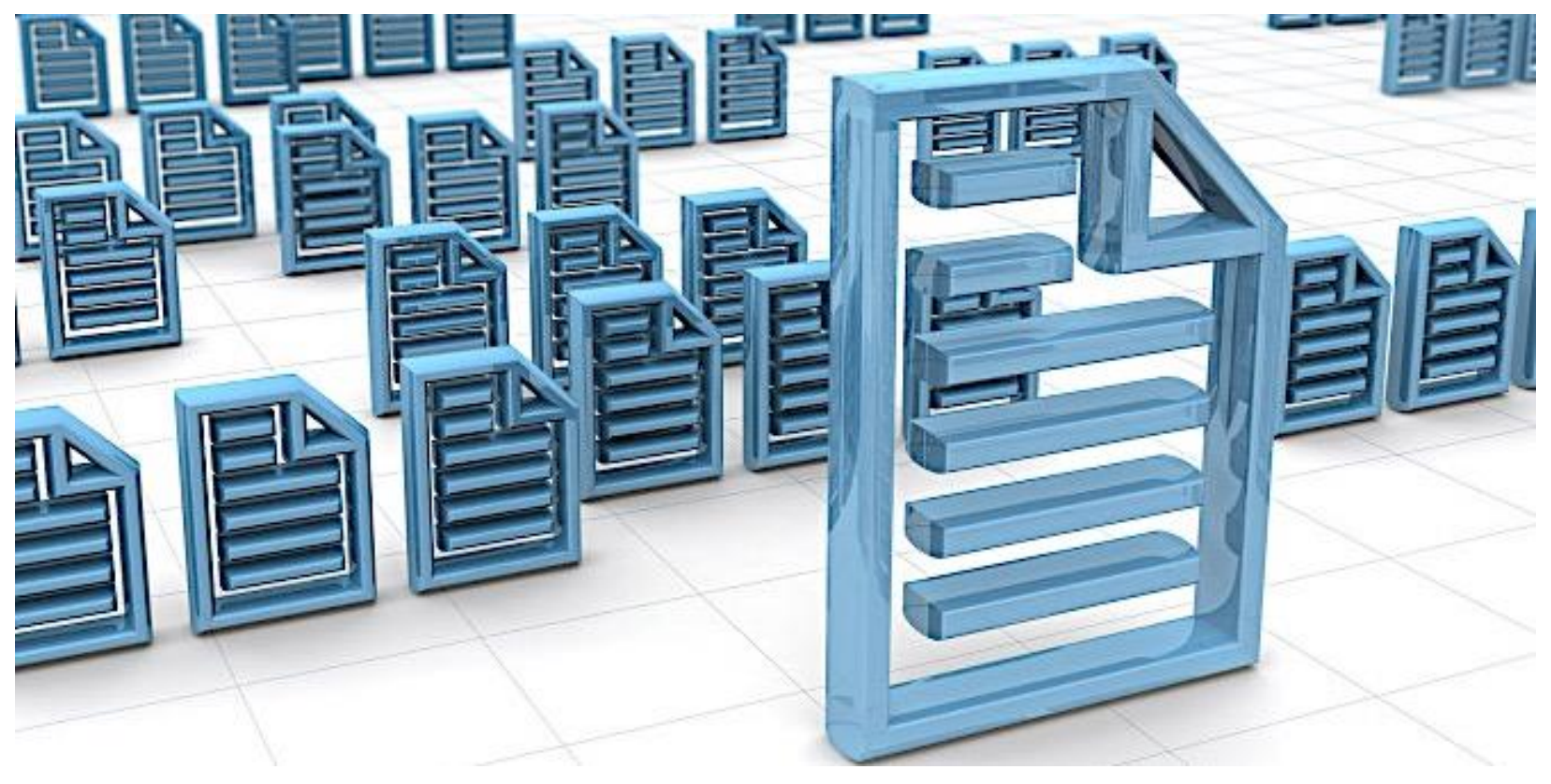

\begin{abstract}
Textbooks are often the primary reference when we think of open educational resources (OER).

While these textbooks are important and offer obvious economic benefits to students, the range of OER is wide and growing. In this paper, we introduce a specific set of OER, under the rubric of the metaliteracy framework, designed to strengthen critical thinking and the overall learning capacities of students. We describe a successful collaboration between an instructor of a political science course and a librarian, which employed these resources to enhance the overall student experience and to focus student attention on becoming more active contributors to their own learning.
\end{abstract}

The authors would like to thank Kelsey L. O'Brien and Karyn Kalita for their reviews of the manuscript and Emily Matott for her reflections on her student experiences in RPOS250. 
Keywords: metaliteracy; OER; collaboration, critical thinking; open educational practices

\section{Introduction}

How do you design an undergraduate course emphasizing critical thinking skills when you are used to teaching classes of a more concrete nature, e.g., Introduction to American Politics or the U.S. Congress? It is of course part of your job as a professor to constantly help students to develop their ideas more clearly and to sharpen their arguments, but how do you make this kind of teaching more explicit? The collaboration referred to in this article's title began with exactly this set of questions when one of the authors was confronted with just such a challenge.

The metaliteracy framework described below provides one set of tools to enhance student critical thinking skills and overall learning. The ongoing professor-librarian dialogue that began with the need to create a new course has led to the application of this framework as a major component of the class. In this paper, we begin by pointing out the enormous potential for open educational resources (OER), we introduce the metaliteracy framework employed here as providing an important set of OER to enhance critical thinking, and we delineate the successful professor-librarian collaboration that has contributed to enhancing the overall student experience and to focusing student attention on becoming more active contributors to their own learning.

\section{Opening Education through OER}

OER benefits both learners and instructors. Students appreciate that these resources cost little or nothing and are available online at any time, while instructors value the array of resources that supplement existing materials, provide inspiration, and engage students (Weller, de los Arcos, Farrow, Pitt, \& McAndrew, 2017). 
While OER are commonly associated with textbooks, they take a variety of forms, from software to massive open online courses (MOOCs) to streaming videos. They range from fairly traditional in their formatting or mode of delivery to innovative and immersive. Just as the format of an OER may vary, so too will its use in a course. An OER may simply be used as a substitute for a non-open resource, with little change in pedagogical method, or it may be the catalyst — or the evidence — of a shift to a more student-centered pedagogical style.

In this regard, a number of scholars have highlighted the vast potential for OER. Gardner Campbell (2012), Associate Professor of English and Special Assistant to the Provost at Virginia Commonwealth University, used the term "opening education" to describe teaching in new ways with new technology. He contrasted it with "open education," which is doing old things with new (OER) technology (Campbell, 2012). Education that is opening "challenge[s] and develop[s] students in owning their learning, engaging with others in their learning, and in innovating..." (Hogan, Carlson, \& Kirk, 2015, Toward Innovative Pedagogies section, para. 3).

Similarly, David Wiley (2013), who developed the 5Rs framework for OER (reuse, revise, remix, redistribute, and retain; Wiley, 2014), illuminated the potential of OER in ways that align with Campbell's opening education:

Using OER the same way we used commercial textbooks misses the point. It's like driving an airplane down the road. Yes, the airplane has wheels and is capable of driving down on the road (provided the road is wide enough). But the point of an airplane is to fly at hundreds of miles per hour - not to drive. Driving an airplane around, simply because driving is how we always traveled in the past, squanders the huge potential of the airplane. 
Finally, Ebba Ossiannilsson (2018), Vice-President of the Swedish Association for Distance Education, recognized the potential of OER to emphasize 21st century competencies and capabilities, including metacognition (p. 106). She argued that OER is an important vehicle for establishing life and work competencies as identified by P21, Partnership for 21st Century Learning (2016):

- Flexibility and Adaptability

- Initiative and Self-Direction

- Social and Cross-Cultural Skills

- Productivity and Accountability

- Leadership and Responsibility

Thus, moving beyond a static textbook as a source of learning to a more expansive use of OER opens the door for a wide range of activities that shift the paradigm from student as content consumer to student as content creator and even to student as director of their own learning. These activities, under the label of open educational practices (OEP), give substance to Wiley's airplane image. Catherine Cronin (2017), a key researcher in the field, summarized OEP based on an in-depth literature review as "moving beyond a content-centered approach, shifting the focus from resources to practices, with learners and teachers sharing the processes of knowledge creation" (p. 17). Definitions and conceptions of OEP vary. Potential components include "Use/reuse/creation of OER and collaborative, pedagogical practices employing social and participatory technologies for interaction, peer-learning, knowledge creation and sharing, and empowerment of learners" (Cronin \& McLaren, 2018, slide 6).

However, there can be a continuum model of practices (Stagg, 2014) or degrees of OEP (Ehlers, 2011, as cited in Cronin \& McLaren, 2018a, p. 130). In courses that employ OEP, 
students generally work with OER and may be active creators of knowledge that will be shared beyond their instructor and potentially beyond their current classmates. In such courses, students move beyond what is seen as the traditional role of "student" to roles that are active, collaborative, and often contribute to the learning of others. Instructors employing OEP, whether partially or fully engaged with the full range of potential practices, need to prepare students for these roles, just as they need to prepare them for the topic of the course. In order for students to succeed, learning must center not only on disciplinary content, but also on a host of competencies that span the behavioral, cognitive, metacognitive, and affective. The metaliteracy conceptualization described below provides a framework for students to better meet unfamiliar learning situations encountered through OER use and for instructors to explore pedagogical practices that allow for opening education.

\section{Metaliteracy}

In an age and information environment where knowledge practices and skills evoking critical thinking are at a premium, the concept of metaliteracy provides a framework and a broad set of OER-based tools with the potential to expand students' and others' learning abilities. The framework is aptly named. One of the meanings of meta in Greek is "beyond," so in the modern day, metaliteracy is what is needed beyond the basic literacies of reading and writing. It “...suggests a way of thinking about one's own literacy. To be metaliterate requires individuals to understand their existing literacy strengths and areas for improvement and make decisions about their learning" (Mackey \& Jacobson, 2014, p. 2). Metaliteracy, therefore, is a pedagogical model that emphasizes an individual's method of learning and participating in today's complex information environment (Mackey \& Jacobson, 2019, p. xvii). Metaliteracy argues against 
passive learning, challenging students to reflect on and take ownership of a host of learner roles while acknowledging the need for incorporating four distinct learning domains.

More specifically, the metaliteracy framework has at its core four goals, each of which has a number of learning objectives (Jacobson, Mackey, O'Keeffe, Forte, \& O'Keeffe, 2018). These learning objectives are underpinned by learning domains designed to emphasize the depth of the learning process: affective, changes in learners' emotions or attitudes through engagement with learning activities; behavioral, what competencies students have upon successful completion of learning activities; cognitive, what students should know upon successful completion of learning activities; and metacognitive, how students reflect on their own learning (Jacobson et al., 2018). It can be revelatory for students to realize, for example, that how they feel about learning something new (affective) may have an impact on that learning (cognitive). They might find that they want to take action (behavioral) in the real world based on new knowledge. Thus, the metaliteracy model is a framework that organizes the domains of learning and gives students a sense that the nature of learning encompasses many more activities than the cognitive domain they likely focus on.

Metaliteracy also asks students to appreciate the different roles that they as learners occupy in today's information environment. It is most common for students - and for many of the rest of us - to think of ourselves simply as consumers of information. The metaliteracy model extends this, encouraging students, in a variety of ways, to think of themselves as information producers. Thus, part of the metaliteracy model delineates a variety of active roles that students consciously or unconsciously use in their own learning process, such as "teacher" (how many times without even thinking about it do you explain to someone else the facts of a situation or the meaning of a concept?), researcher (how many times a day do you go to Google to look up a 
specific set of facts?), or translator (consider times when you encounter something in one medium and then "translate" it into another medium, e.g., talk to a friend about what you have read). Thus, metaliteracy emphasizes the variety of ways that students are able to go beyond the relatively passive role of information consumer and take charge of their learning. The four learning domains and the learner roles can be seen in Figure 1: The metaliterate learner.

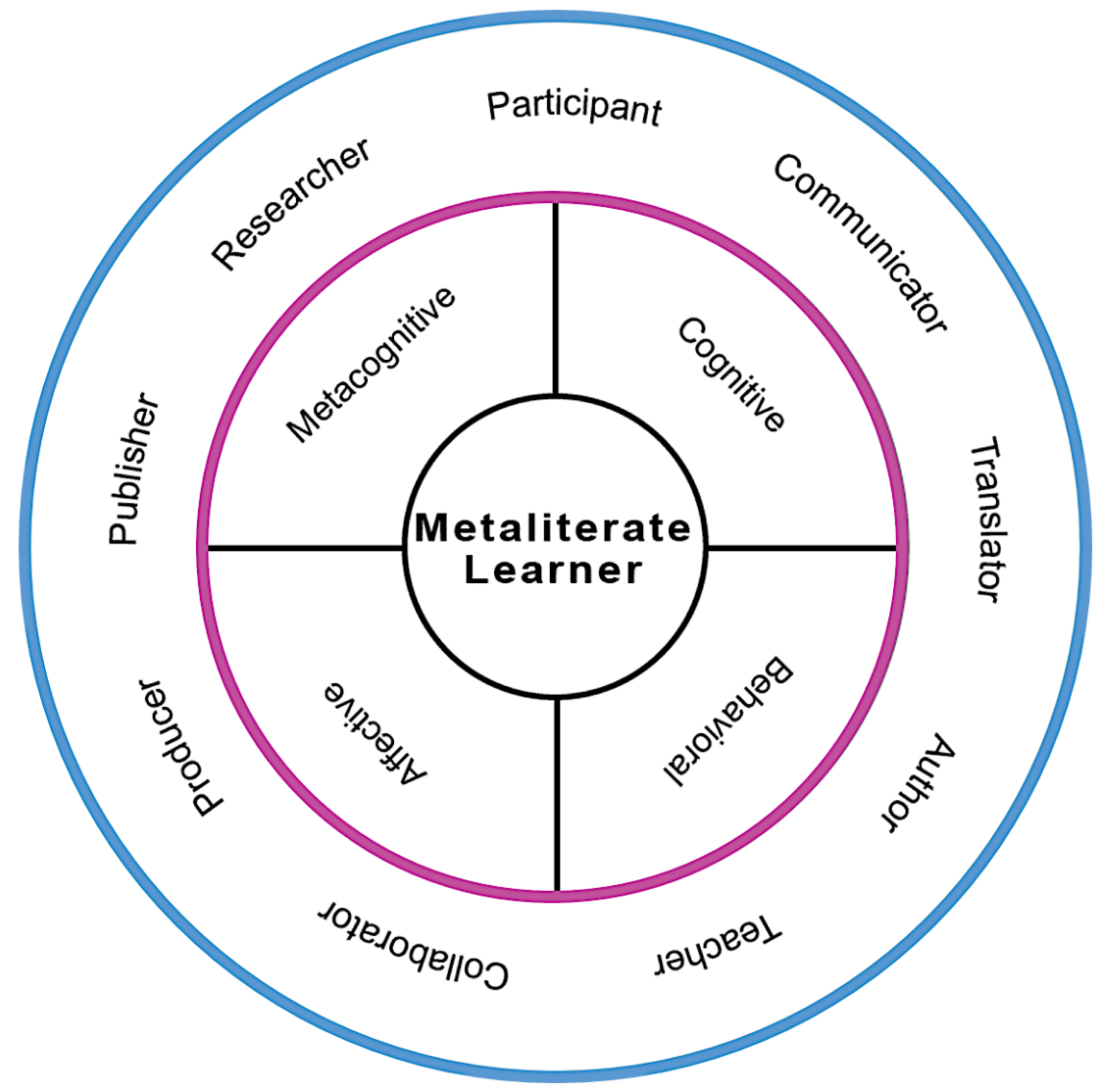

Figure 1: The metaliterate learner.

Metaliteracy goals and learning objectives. The four core goals, with selected learning objectives, are:

Goal 1: Actively evaluate content while also evaluating one's own biases Objectives: 
Critically assess information from all sources, including dynamic content that circulates online. (Behavioral)

Examine how you feel about the information presented and how this impacts your response. (Affective, Metacognitive)

\section{Goal 2: Engage with all intellectual property ethically and responsibly}

Objectives:

Responsibly produce and share original information and ethically remix and repurpose openly licensed content. (Behavioral)

Distinguish between public and personal information and make ethical and informed decisions about appropriately sharing information online. (Cognitive)

\section{Goal 3: Produce and share information in collaborative and participatory environments}

Objectives:

See oneself as a producer as well as consumer of information. (Affective, Metacognitive) Participate conscientiously and ethically in collaborative environments. (Behavioral) Recognize diverse cultural values and norms to create and share information for global audiences. (Behavioral, Cognitive)

\section{Goal 4: Develop learning strategies to meet lifelong personal and professional goals}

Objectives:

Value persistence, adaptability, and flexibility in lifelong learning. (Metacognitive) Adapt to and understand new technologies and the impact they have on learning. (Affective, Behavioral)

Engage in informed, self-directed learning that encourages a broader worldview through the global reach of today's social media environment. (Behavioral, Metacognitive) 
While students may not necessarily relate to the full list of goals and learning objectives (Jacobson et al., 2018), the metaliterate learner roles translate these statements into a form that students can embrace and own. The defined roles enable students to fulfill what might otherwise be unstated obligations in academic settings and through lifelong learning efforts. The range and content of these obligations drawn from the goals and learning objectives are made palpable in a way that individuals do not confront in other settings or frameworks. While metaliteracy is focused on self-directed learning, it is a framework that students are not familiar with. Therefore, the instructor's role in introducing students to metaliteracy and guiding their initial engagement with it is appropriate and necessary.

Metaliteracy's goals and attendant learning objectives speak to important knowledge, competencies, and attributes required for today's information environment. They not only address the 21st century competencies raised by Ossiannilsson (2018), but also three of the four specific "C" skills identified as the most important for student success at college, in their careers, and as citizens: critical thinking, communication, and collaboration (National Education Association, n.d.). While creativity, the fourth "C," is not a stated metaliteracy learning objective, it is inherent in those that address teaching and translating information for diverse audiences.

Metaliteracy can also serve a second purpose for courses using OEP. It has the potential to scaffold the use of these practices, asking students to reflect on their roles as learners and contributors. Courses that use OEP expand student agency, and preparation for this increased and often unfamiliar obligation assists students' ability to succeed. 


\section{Metaliteracy OER}

In order to incorporate the metaliteracy framework in courses, the Metaliteracy Learning Collaborative has created a wide range of OER for teaching and learning metaliteracy. The collaborative is comprised of State University of New York librarians, disciplinary faculty members, and instructional designers, each of whom brings particular knowledge and perspectives to the creation of OER. The resources include a digital badging system with tiered content in the form of quests and challenges, MOOCs, a Lumen Learning college success module for high school seniors/college first year students, and more. The collaborative encourages student collaboration in OER creation, and several components of these resources have been developed by students who are credited in the resources themselves. All of these OER are available to interested librarians and disciplinary faculty members and readers are invited to explore, use, and adapt them.

Metaliterate learner badging system. The badges from this multi-tiered resource include activities based on the metaliteracy goals and learning objectives that culminate in four badges: Master Evaluator, Producer and Collaborator, Digital Citizen, and Empowered Learner, as shown in Figure 2. The Master Evaluator badge includes two units: Content Analysis (search strategizing, evaluation, packaging and sharing of information) and Perspectives and Responses (author's voice, individual and collaborative creation). The Producer and Collaborator badge includes a Global Contributor unit (participate, listen and learn, and share) and a Creator unit (produce, expand horizons). Digital Citizen has Information Ethics content (intellectual property and information use) and a Social Identity section (online personas and personal privacy). The fourth badge, Empowered Learner, has three sections (metacognitive reflection, critical thinker, and learner as teacher). Learners are able to demonstrate understanding through the written 
assignments that accompany each activity submitted to instructors for review. Metacognition plays an important part in the increasingly reflective activities students are asked to complete as they move from the entry level content to more integrative material. While the badge-tracking component of the platform is currently under development, the content of all activities and assignments is freely available to any interested instructor or learner (https://sites.google.com/view/metaliteracy).

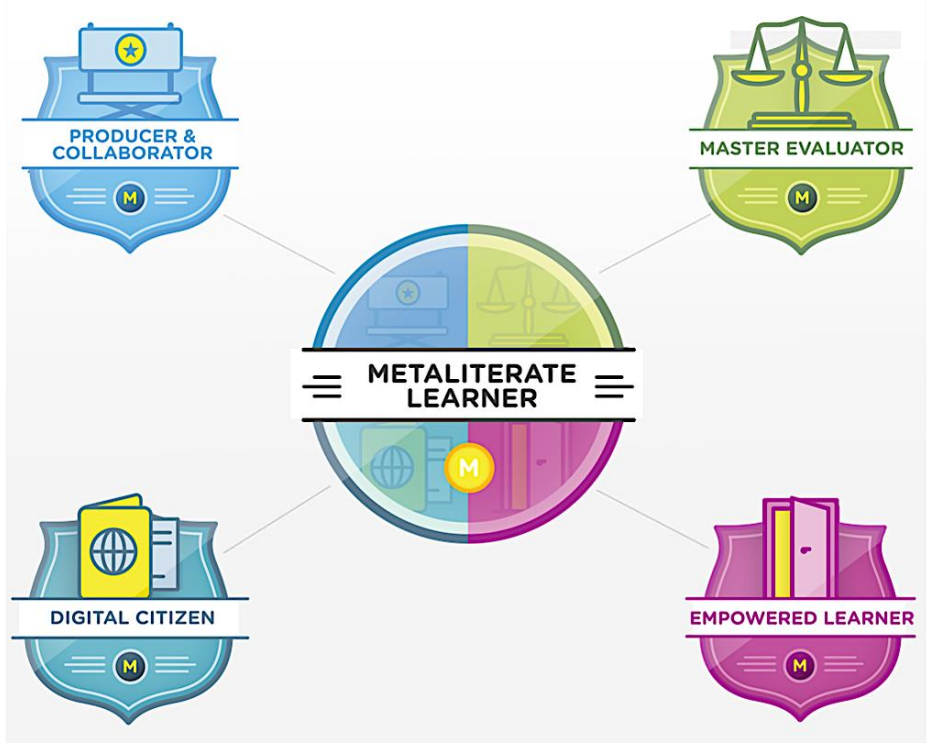

Figure 2: Metaliterate learner badges.

Metaliteracy: Empowering yourself in a connected world MOOC. This MOOC

features videos, readings, discussions, and learning activities that promote metaliteracy competencies. It is available on the Coursera platform, with frequent course start dates. There is no charge for the course unless one would like to earn a Coursera certificate of completion (https://www.coursera.org/learn/metaliteracy).

Empowering yourself in a post-truth world MOOC. This 2019 self-paced MOOC addresses issues connected to the post-truth world in which factual information has been displaced by subjective and biased viewpoints. It asks participants to gain insights into their own 
biases and preconceptions. It uses metaliteracy to teach self-reflective, metacognitive processes and examine fixed mindsets, and empowers learners to be responsible consumers and producers of information. It was first offered on the Open edX platform, and is now available on Coursera (https://www.coursera.org/learn/empowering-yourself-post-truth-world).

Metaliteracy iSucceed module. This learning resource, offered via Lumen Learning, consists of five units that introduce high school and first year college students to components of metaliteracy. The units include the following activities and self-check questions:

- What Does it Mean to Be a Metaliterate Learner?

- Metaliteracy and Your Role as a Researcher

- Your Role as an Information Producer and Collaborator

- Your Life as a Metaliterate Digital Citizen

- Being a Lifelong Metaliterate Learner

\section{(https://courses.lumenlearning.com/isucceed-wm-collegesuccess/)}

Metaliteracy learner roles prompts. These questions prompt students to think about each metaliterate learner role more deeply, and are designed so that students will make connections between what they know and do and the roles (https://metaliteracy.org/ml-inpractice/metaliterate-learner-roles/).

\section{Metaliteracy and OER: Collaborative Course Development for Critical Thinking}

How does one move from the theory of critical thinking to teaching it in a particular course? Where does metaliteracy come in? The authors of this article have worked together over four iterations of a relatively new course, Research and Method in Political Science, designed to assist in the teaching of critical thinking to undergraduates. Created particularly for transfer students, the course also meets several competencies encouraged for students within the Political 
Science major - information literacy, advanced writing, and oral discourse — all of which have an obvious connection to critical thinking.

The instructor, confronted with the challenge of preparing a new class, sought the assistance of the librarian to assess the availability of resources. Collaboration between the course instructor and the librarian began in the specific context of developing the information literacy requirement. The first time the course was offered, two librarians jointly taught an introductory class, with the subject librarian for political science addressing databases and other important tools and some key search strategies, while the author explored metaliteracy. The course professor then decided that the metaliteracy framework - with its focus on alternative domains of learning, active learning roles, and the critical thinking competencies honed by the metaliteracy quests - aptly fit the bill for future sections of the course.

While there are clearly many ways to accomplish the goal of teaching this kind of class, the instructor chose to develop a course that would make abstract policies more concrete. Thus, each semester students have been asked to focus on four or five units, each highlighting a current and controversial political issue or concept. Students are required to become familiar with alternative perspectives on each issue or concept and subsequently develop their own positions. Topics were selected for their potential to involve different contexts for critical thinking — asking students, for instance, to consider issues as a generalist (making a budget) or as a policymaker tasked with a very specific role (handling the opioid crisis); or asking students to consider issues where they were likely to have strong opinions (income inequality) in contrast to issues with which they might be less familiar (globalization). As examples, in the fall 2019 semester the instructor developed a unit on migration/immigration, first considering some specific policies (e.g., green light laws, sanctuary cities), then stepping back to focus on broader principles 
including the advantages and disadvantages of open versus closed borders and the relevance of theories of American identity, finally cycling back to apply these broader perspectives to additional current-day issues. The generation unit of the course asks students, in light of the fact that people tend to pay attention to demographic characteristics such as race or gender over and above any effect of age, to focus on what it means to be part of a generation and what impact "generation" might have as they move forward with their lives. The instructor and students then consider aspects of "generation" (e.g., political socialization, the acquisition of political information, political participation) that are particularly relevant to the lives of younger generations and that also enhance one's critical thinking capabilities. For example, the more you yourself think about how you have been socialized, the better you can reflect on your own perspective, potentially making it more likely that you will be able to sort out the perspectives of others. The more you become aware of the sources of information you utilize, the more likely you might be to take the initiative to expand the range of available options.

\section{Incorporation of Metaliteracy}

When introducing metaliteracy to the instructor, the librarian described the aforementioned metaliteracy learner badges, which are specifically designed for use in courses regardless of discipline and are flexible in the content that can be selected and, if desired, adapted. While the learning system is structured around four master badges, instructors may choose to mix and match the quests (the lowest level of activity) that they assign. Students who complete the full series of required activities are able to earn a digital badge, attesting to their competency, but interested instructors can create badges that acknowledge meaningful subsets of the content. 
After discussion, activities were selected from the metaliterate learner badges that complemented course topics. In particular, a variety of quests - who wouldn't be intrigued by the idea of a quest particularly at the height of HBO's Game of Thrones series? —were picked to increase student engagement and to serve as short assignments to augment the writing requirement. Some students perceive writing responses to quests as more user-friendly than a standard academic paper. By the third iteration of the course, 10 quests were being used; the current iteration of the course requires nine. The assigned quests specifically relate to critical thinking — for example, the "Reevaluate" quest asks students to think about a current decision they are facing and reconsider it in light of critical thinking criteria. The "Giving Credit" quest focuses on the importance of acknowledging sources in an era where it is easy to take for granted where information comes from. The "Expand Horizons" quest asks students to take a specific course topic (generally this has been done in the context of the "generations" unit) and put their own stamp on it by compiling their own set of video and written sources and presenting them to the class. Appendix 1 provides the instructions students work from to create this quest.

Lastly, a culminating assignment asks students to design their own quest, exemplifying the learner as producer. By this point in the semester, students have considerable exposure to metaliteracy concepts and the quest format as well as to the specific topics covered in class. The "Design Your Own Quest" assignment asks students to create a quest about a topic of importance to them that had not been covered in the course and to present it to the rest of the class.

The quests used in the course were selected from different parts of the learning system, and therefore did not accrue an existing digital badge upon completion. The authors thus created the Expanding Horizons badge, which is unique to this customized selection of activities. 
Students learned that digital badges reflect mastery of a micro-competency and that they can share this achievement on social media and online resumes.

From an open pedagogical perspective, students who have written high quality quests are offered the option to have them considered for inclusion in the badging system content. To date, one graduate student—whose quest was on the ways in which the sport of baseball united different generations of families in Taiwan—has shared his quest in this way. Although the emphasis so far has been on getting the students to turn in specific course assignments, future iterations of the course will put more emphasis on encouraging students to work toward this more public option.

\section{Impact of Metaliteracy OER}

Over the course of the four semesters that this particular instructor has offered the course, the metaliteracy framework has proved useful and has accounted for a significant portion (20\%) of a student's grade. As is clear from the description of metaliteracy, there are a number of components - the framework itself, the learning domains, the learner roles (producer, teacher, researcher, etc.), and the quests that draw upon the goals and learning objectives. The OER both clarify and expand these components, with the quests and higher-level activities from the badge content the most in-depth. Notwithstanding the inherent variation in student attention and interest, in general, students in the political science course understand the overall framework. They understand the idea that they are producers as well as simply consumers of information, and at its broadest level, they recognize that metaliteracy is asking them to process information in ways that go well beyond the cognitive domain.

Throughout the class, the instructor also emphasizes the accompanying metaliterate roles. The students in one class section asked the librarian for more detail about what exactly each role 
entailed, resulting in the development of the clarifying role prompt OER that has since been used in a number of other learning settings (Jacobson, Mackey, \& O’Brien, 2018). In class, the professor incorporates specific roles in group activities - students pick the roles they think they need to improve on and at several points in the course are asked to engage in activities that will help them do so in conjunction with the particular topic being studied. If students want to become better researchers, they are asked to generate some new and interesting facts on the issue under discussion. If they want to improve as teachers, each student will be asked to explain an idea or two to another student.

As the instructor came to appreciate its value and became more comfortable explaining it to the class, the metaliteracy framework played a larger role in each semester. The quests, along with the culminating badge, have proven integral to the course. Despite the strong comment from one student claiming he would rather take an exam than develop a quest, impressionistically the students have seen the quests as favorable alternatives to "yet another paper." They appreciate that many of the quests are short and to the point. They also like the open-ended nature of some of the quests, particularly the "Expanding Horizons" quest, and the flexibility of picking their own topics for the "Design Your Own Quest" assignment.

Despite some understandable nervousness about formally speaking in front of the whole class, students also appreciate the resources used in the class presentations. One student wrote, "the quests not only put the students in a more central role in learning, but the presentations component allows for students to see how their classmates tackled the quests, furthering ideas of how they could look at similar situations in the future and how to further use the skills and knowledge they've gained” (E. Matott, personal communication, July 28, 2019). 
Overall success notwithstanding, critical thinking is not easy to teach. Students respond most readily to the specific quests because they are the most concrete aspect of the metaliteracy framework. Although students come away with a general appreciation of the value of this set of OER, it falls to the instructor to frequently remind them about the broader learning context. The incorporation of the metaliteracy framework makes this job easier and would not have happened without the instructor-librarian collaboration.

\section{Conclusion}

In this paper, the authors have expanded an appreciation for OER by describing the metaliteracy framework, which demonstrates that the value of OER goes well beyond the provision of online textbooks for students. In turn, the metaliteracy framework provides a multipronged conceptualization to help students place the cognitive skills they usually highlight into a broader perspective including affective, behavioral, and metacognitive domains. The framework teaches students to become better critical thinkers and more effective and responsible citizens, thus embodying the spirit of the 4 Cs (critical thinking, communication, collaboration, and creativity) that have been cited as essential skills for 21 st century learners. It empowers students to take on more active roles both within and outside of the academic setting and provides scaffolding for open pedagogical practices.

In explaining how this framework has been successfully adapted to the needs of one classroom context, the authors have also demonstrated the flexibility of the metaliterate approach. The active metaliterate learner roles have been clarified over successive iterations of this particular course to assist student understanding. The instructor has developed the "Design Your Own" quest assignment and adapted the "Expand Horizons" quest activity for use in larger political science courses that are centered on disciplinary rather than explicitly critical thinking- 
focused content, and adaptations to the metaliteracy OER developed in conjunction with this particular political science course have since been used by other professors at the University at Albany and beyond.

Finally, given that professors often underutilize the knowledge and assistance of librarians, the paper provides a reminder of the benefits of collaborative work. Faced with the challenge of creating a new course, the professor searched for resources that would assist in teaching critical thinking. In the collaborative spirit promoted by metaliteracy and OER, the successful professor-librarian partnership described in this paper has made that course significantly better.

\section{References}

Campbell, G. (2012, October 16). Ecologies of yearning. Keynote address at Open Ed 2012 Conference. Retrieved from https://www.youtube.com/watch?v=kIzA4ItynYw

Cronin, C. (2017). Openness and praxis: Exploring the use of open educational practices in higher education. The International Review of Research in Open and Distributed Learning, (18)5, 16-34. Retrieved from http://www.irrodl.org/index.php/irrodl/article/view/3096/4263

Cronin, C., \& MacLaren, I. (2018, April 24). Conceptualising OEP: A review of theoretical and empirical literature. Presented at CELT, NUI Galway. Retrieved from https://schd.ws/hosted_files/oeglobal2018/ff/Conceptualising\%20OEP.pdf

Cronin, C., \& McLaren, I. (2018a). Conceptualising OEP: A review of theoretical and empirical literature in open educational practices. Open Praxis, 10(2), 127-143. doi:10.5944/openpraxis.10.2.825

Hogan, P., Carlson, B. R., \& Kirk, C. (2015, April). Open educational practices' models using open educational resources. Presented at the Open Education Global Consortium Conference, Banff, Alberta, Canada. Retrieved from https://commons.nmu.edu/cgi/viewcontent.cgi?referer=https://www.google.com/\&httpsre dir $=1 \&$ article $=1064 \&$ context=facwork_conferencepapers

Jacobson, T. E., Mackey, T., \& O’Brien, K. (2018). Metaliterate learner roles. Retrieved from Metaliteracy website: https://metaliteracy.org/ml-in-practice/metaliterate-learner-roles/ 
Jacobson, T. E., Mackey, T., O'Keeffe, E., Forte, M., \& O'Keeffe, E. (2018). Metaliteracy goals and learning objectives. Retrieved from the Metaliteracy website:

https://metaliteracy.org/learning-objectives/

Mackey, T. P., \& Jacobson, T. E. (2014). Metaliteracy: Reinventing information literacy to empower learners. Chicago, IL: ALA Neal-Schuman.

Mackey, T. P., \& Jacobson, T. E. (Eds.). (2019). Metaliterate learning for the post-truth world. Chicago, IL: ALA Neal-Schuman.

National Education Association. (n.d.). Preparing 21st century students for a global society: An educator's guide to the "four Cs." Retrieved from http://www.nea.org/assets/docs/AGuide-to-Four-Cs.pdf

Ossiannilsson, E. (2018). Ecologies of openness: Reformations through open pedagogy. Asian Journal of Distance Education, 13(2), 103-119.

P21: Partnership for 21st Century Learning. (2016). Framework for 21st Century Learning. Retrieved from P21 website:

http://www.nea.org/home/34888.htmfile:///Users/trudi/Downloads/P21_framework_0816 _2pgs.pdf

Weller, M., de los Arcos, B., Farrow, R., Pitt, R., \& McAndrew, P. (2017). What can OER do for me? Evaluating the claims for OER. In R. S. Jhangiani \& R. Biswas-Diener (Eds.), Open: The philosophy and practices that are revolutionizing education and science (pp. 67-77). doi: $10.5334 /$ bbc.e

Wiley, D. (2013, October 21). What is open pedagogy? Retrieved from Iterating Toward Openness website: https://opencontent.org/blog/archives/2975

Wiley, D. (2014, March 5). The access compromise and the 5th $R$. Retrieved from Iterating Toward Openness website: https://opencontent.org/blog/archives/3221 


\section{Appendix 1}

\section{Directions for Creating an Expand Horizons Quest (2016)}

Your task: To create an engaging, informative Expand Horizons quest

Learning objectives: produce, share, and evaluate information in a variety of participatory environments; conduct ethical practices in the use of information, in ways that demonstrate awareness of issues of intellectual property; and broaden your own understanding of generations and politics.

Metaliteracy, as you know, emphasizes that learners are creators of information, as well as consumers. In this activity, you will have the opportunity to:

- Assume the role of creator

- Be creative and have fun

- Engage in a learning activity that allows you to inform others

- Further your learning about the topic of generations in connection with political science

- Possibly write for a larger public if your quest is used or adapted for the Metaliteracy badging system (permission will be asked of you)

In this activity, you will be considering how you might expand the horizons of other learners in connection with the course theme of generations. This might involve a historical look at generations, a glimpse into generations in other countries or other cultures, or some other specific aspect of generations that you can connect with political science. Or it might involve an unusual juxtaposition of topics or content formats.

You will be creating a quest that connects this idea of expanding horizons with the course content of generations. To do this, you need to know what a quest looks like, and what they try to accomplish. You aren't creating this only for your professor to review, but for a wider audience. Below, you will find out how to prepare yourself for this assignment, what you need to do to successfully complete it, and how you will share it.

Because this assignment is rather unusual, it behooves you to read these directions carefully. It will definitely make the assignment less confusing for you! If you have questions, feel free to contact Professor Jacobson.

\section{Prepare}

Prepare yourself by reading the following:

1. The Metaliterate Learner handout you were assigned earlier, to review the 4 learning domains 
2. Two quests in the badging system, to reiterate what quests are!

Giving Credit Quest

https://sites.google.com/view/metaliteracy/master-evaluator/perspectivesresponses/authors-voice/giving-credit?authuser $=0$

Grow vs. Fail Quest

https://sites.google.com/view/metaliteracy/empowered-

learner/metacognitive-reflection/failing-better/grow-vs-fail?authuser $=0$

3. The Universal Design for Learning Guidelines (UDL)

http://www.cast.org/our-work/about-udl.html\#.V-K1dzVFHMx

(look at the 3 boxes about the WHY, HOW, and WHAT of learning, and perhaps click through to the UDL Guidelines)

\section{Create}

1. Recognize that you would like to engage readers in the topic of generations (in connection with political science), help them to learn something (cognitive) and reflect upon it (metacognitive). You might also have them do something (behavioral) or they might come to feel something about this content you are creating (affective). You may also present information in different ways or provide different options for the final activity (UDL).

2. The toughest part about writing a quest is coming up with an angle. What aspect of generations would you like to present that fits the theme of Expanding Horizons for those who are reading it? How can you make it interesting?

3. Once you've decided on your topic and angle, find something engaging to let learners know about it. It might be a video, a short reading, or something else entirely. Make sure you cite your sources!

4. Find a way to tell a story. In other words, provide background, fill in gaps, make this quest cohesive. What would you like learners to come away with?

5. Next, develop an activity (or choice of activities, keeping UDL in mind) to let learners take the topic further, or to explore and reflect on what they've learned.

6. Pull it all together, and get ready to present this to the class 